\title{
BRANCH-TO-STEM DIAMETER RATIO AFFECTS STRENGTH OF ATTACHMENT
}

\section{by Edward F. Gilman}

\begin{abstract}
Strength of branch attachment in Acer rubrum L. was related to the ratio of diameter of the branch relative to the diameter of the stem to which the branch was attached (aspect ratio). Linear correlation coefficients ranged from -0.25 to -0.90 between aspect ratio and load (force) required to separate branches from stems at the branch union. Slopes of the lines describing this relationship increased with increasing branch diameter. This indicated that larger branches required greater force to pull them from the trunk provided they were small compared to the trunk. However, diameter had less of an influence on force required to pull codominant stems apart. Force per unit of branch cross-sectional area was related $\left(\mathrm{R}^{2}=56 \%\right)$ to aspect ratio, indicating that a branch of a given size was better secured to the tree if it was attached to a much larger stem than to a stem of equal size. Angle of attachment was not related to strength of branch attachment. Codominant stems were far easier to split apart than branches that were small relative to stem size. Codominant stems broke by separating at the union; branches failed by breaking at or near the collar. This information has implications for arborists climbing trees and will help guide development of pruning strategies.
\end{abstract}

Key Words: Branch failure; aspect ratio; collars; Acer rubrum.

In the early and middle part of the last century, MacDaniels (1923) and others (Ruth and Kelley 1932; Verner 1955) believed that the strength of branch attachment was largely governed by the angle of attachment. Each showed elegant data supporting their conclusion. Later work questioned this concept (Miller 1958) and showed that previous researchers had ignored important factors that were spuriously correlated with angle such as branch size relative to trunk size and presence of included bark. Even MacDaniels' later work (1932) recanting his previous work (1923) was largely ignored, perhaps because it was published in abstract form only-a full manuscript was never published. Most recently, Lilly and Sydnor (1995) found no relationship between branch angle and strength of attachment for two commonly grown maples trees.

Researchers have theorized (McMahon 1975), inferred (Miller 1958; Edberg et al. 1994), and observed (MacDaniels 1923) that the size of the branch in relation to trunk size may have something to do with strength of attachment to the trunk. But studies testing the effects of branch:trunk diameter ratio have not been performed in great numbers, especially on shade tree species. MacDaniels (1932) might have been one of the first researchers to conduct an experiment specifically designed to evaluate the impact of size ratio on strength of the branch union. He found that the weight required to break any given branch or union (crotch) of a certain diameter decreased as the size of trunk it was attached to decreased. It was easiest to break the branch near its base or pull the branch from the trunk when both branch and trunk were of the same diameter. Other defects associated with branch failure include long, heavy limbs and codominant stems (MacDaniels 1923; Edberg et al. 1994) and bark inclusions in the union (MacDaniels 1932; Miller 1958).

Collars form around the base of branches to help them remain attached to the trunk (Shigo 1985). The overlapping branch and trunk tissue in the collar helps physically secure the branch to the trunk. If the collar forms improperly or is lacking, then branches may not be well secured to the trunk. Codominant stems typically lack the overlapping tissue present in a collar, which may be why trees with this defect split so easily (Edberg et al. 1994).

The objectives of this study were (1) to determine if strength of red maple branch attachment was related to branch diameter:trunk diameter ratio, and (2) to determine if branch diameter affected this relationship.

\section{MATERIALS AND METHODS}

One hundred branches from ten red maple (Acer rubrum L.) trees approximately 10 years old were pulled from the trunk in the following manner. The trunk immediately above a branch union to be tested was secured to a fixed object with a nonstretchable rope. The rope was positioned about horizontally, perpendicular to the trunk. A metal loop was placed on top of the branch base just outside the branch bark ridge. A rope was secured to the loop and tied to a load cell and then to a winch. The branch was pulled slowly with the winch until the branch union split, resulting in a separation several centimeters down the trunk (union failure), or it broke at or near its base, leaving the collar more or less intact without a split down the trunk (branch failure). The load was applied downward perpendicular to the top of the branch. The maximum load indicated on the load cell was recorded as the load required to separate the branch from the trunk.

Branch:trunk diameter ratios ranged from 0.25 to 1.0. Branch:trunk diameter ratios were measured as the diameter of the branch beyond any swollen collar just outside 
the branch bark ridge divided by the diameter of the trunk to which the branch was attached measured directly above the branch bark ridge. Branch diameters ranged from 5 to $20 \mathrm{~mm}$. Angle of branch attachment was measured with an adjustable angle and a protractor.

General linear models procedure was used to calculate slopes of lines relating load to breakage and stress (newtons $/ \mathrm{mm}^{2}$ ) versus branch:trunk diameter (aspect) ratio. The t-test was used to test equality of slopes among branch diameters $(\mathrm{P}<0.01)$. Stepwise regression $(\mathrm{P}<0.01)$ was performed to build a model predicting load required to break the branch or separate the union using the following as independent variables: angle of attachment, branch diameter, and ratio of branch diameter:trunk diameter.

\section{RESULTS AND DISCUSSION}

Similar to Norway (Acer platanoides) and silver maples (A. saccharinum) (Lilly and Sydnor 1995) and apple (Malus) (MacDaniels 1932), there was no relationship between angle of branch attachment and strength of branch attachment (load required to separate branch from trunk). Upright branches were secured to the trunk as well as more horizontal branches.

Strength of branch attachment was correlated with branch:trunk diameter ratio and branch diameter (Equation 1 and Figure 1). $R^{2}$ values ranged from 0.25 to 0.90 (depending on branch diameter) between branch:trunk diameter ratio and load required to separate branches from stems (Table 1). Slopes of the lines describing this relationship increased with branch diameter. This indicated that larger branches required greater force to pull them from the trunk provided they were small compared to the trunk. However, diameter had little influence on force required to pull codominant stems apart. Codominant stems were far easier to split apart than a similar sized branch that was small relative to trunk size. This finding agrees with MacDaniels (1932) and Miller (1958) for apple trees. The force per unit cross-sectional branch area required to pull a branch from a trunk was correlated with the aspect ratio (branch:trunk diameter ratio) (Figure 1).

\section{Equation 1}

Load $(\mathrm{Kg})$ to branch union failure $=0.88$ (branch:trunk ratio $)+18.84$ (branch diameter $)-0.17$ (ratio $\times$ branch diameter) $-88.85 ; \mathrm{R}^{2}=0.84 ; \mathrm{P}<0.001$

Branch:trunk ratio $=$ the diameter of the branch at its base divided by the diameter of the trunk measured directly above the branch bark ridge; branch diameter = diameter of the branch just beyond the branch bark ridge and collar.
Table 1. Equations of the line predicting force $(\mathrm{kg})$ required to separate branches from the trunk versus branch:trunk diameter ratio for various branch diameters.

\begin{tabular}{ll}
\hline Branch diameter & Equation relating force vs. branch:trunk diameter ratio \\
\hline $5.0-5.9 \mathrm{~mm}$ & force $=-12.2($ ratio $)+19.2, \mathrm{R}^{2}=.25$ \\
$6.0-6.9 \mathrm{~mm}$ & force $=-41.0($ ratio $)+45.2, \mathrm{R}^{2}=.53$ \\
$7.0-7.9 \mathrm{~mm}$ & force $=-39.1($ ratio $)+47.7, \mathrm{R}^{2}=.50$ \\
$8.0-8.9 \mathrm{~mm}$ & force $=-43.9($ ratio $)+57.3, \mathrm{R}^{2}=.45$ \\
$9.0-9.9 \mathrm{~mm}$ & force $=-69.1($ ratio $)+84.6, \mathrm{R}^{2}=.58$ \\
$10.0-10.9 \mathrm{~mm}$ & force $=-66.9($ ratio $)+90.12, \mathrm{R}^{2}=.65$ \\
$11.0-11.9 \mathrm{~mm}$ & force $=-137.8($ ratio $)+146.8, \mathrm{R}^{2}=.79$ \\
$12.0-12.9 \mathrm{~mm}$ & force $=-155.1($ ratio $)+165.1, \mathrm{R}^{2}=.89$ \\
$13.0-13.9 \mathrm{~mm}$ & force $=-158.6($ ratio $)+165.6, \mathrm{R}^{2}=.86$ \\
$14.0-20.0 \mathrm{~mm}$ & force $=-190.5($ ratio $)+217.3, \mathrm{R}^{2}=.90$ \\
\hline
\end{tabular}

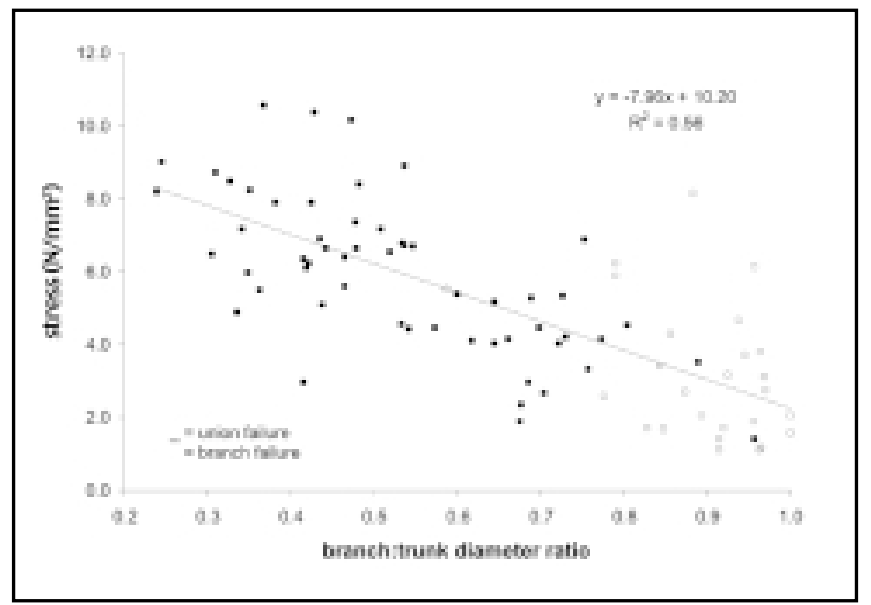

Figure 1. Stress (in newtons $/ \mathrm{mm}^{2}$ ) required to separate a branch from the trunk for a variety of branch:trunk diameter ratios.

The overlapping of trunk and branch tissue in the union could be readily seen under a $10 \times$ lens following branch pulling on branches that were small compared to the trunk. The woody tissues of the branch at the top and the sides of the union appeared to fit into the trunk tissues somewhat like how screw threads fit into wood. Pulling small branches from larger trunks was much like attempting to pull a screw from a piece of wood. Doing so is difficult because the threads trap wood between them making it tough to pull out. On the other hand, splitting codominant stems was much like splitting logs for firewood. It was easy because a force was being applied along the rays where natural cracks exist. There was no compacted xylem (Shigo 1985), which contains overlapping wood, at the base of codominant stems.

This information has implications for arborists climbing trees and will help guide development of pruning strategies. It suggests that the tree form that would result in the least amount of breakage is one in which branches remain small 
compared to the trunk. The same recommendation came from work on discoloration resulting from pruning cuts (Eisner et al. 2002). Results also suggest that the larger the branch diameter, the more important it is for it to be small in relation to the trunk. Pruning techniques that slow the growth rate of developing codominant stems and large vigorous branches would encourage this tree structure.

The failure pattern of branches that remained small in comparison to the trunk will make it simpler to repair trees following storm damage compared to damage resulting from codominant stem failure. Branches with a small aspect ratio typically broke near the collar, making it fairly simple to remove them back to the collar. Large-diameter branches and codominant stems split at the union down the trunk. This injury is much more severe and can result in trunk defects (Shigo 1985).

The limitations of this research should be clear. Small branches were used, and only one species was studied. This work should mark the beginning of much more extensive studies aimed at determining the best structure for trees located in urban and suburban landscapes. Larger trees should be tested and this information refined for a variety of taxa.

\section{LITERATURE CITED}

Edberg, J., A.M., Berry and L.R. Costello. 1994. Patterns of tree failure in Monterey pine. J. Arboric. 20:297-304.

Eisner, J.N., E.F. Gilman, and J.C. Grabosky. 2002. Branch morphology impacts compartmentalization of pruning wounds. J. Arboric. 28:99-105.

Lilly, S., and T.D. Sydnor. 1995. Comparison of branch failure during static loading of silver and Norway maple. J. Arboric. 21:302-305.

MacDaniels, L.H. 1923. The apple-tree crotch. Cornell Univ. Agric. Exp. Sta. Bull. 419:1-22.

1932. Factors affecting the breaking strength of apple tree crotches. Abstract, Proc. Am. Soc. Hortic. Sci. 29:44.

McMahon, T.A. 1975. The mechanical design of trees. Sci. Am. July:92-102.

Miller, V.J. 1958. Crotch influence on strength and breaking point of apple tree branches. J. Am. Soc. Hortic. Sci. 73:27-32.

Ruth, W.A., and V.W. Kelley. 1932. A study of the framework of the apple tree and its relation to longevity. Ill. Agric. Exp. Sta. Bull. 376.

Shigo, A.L. 1985. How tree branches are attacked to trunks. Can J. Bot. 63:1391-1401.

Verner, L. 1955. Hormone relations in the growth and training of apple trees. Idaho Agric. Exp. Sta. Res. Bull. 28.

Acknowledgments. Florida Agricultural Experiment Station Journal Series Number \# R-09271.

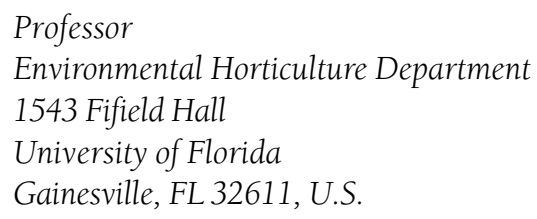


Résume. La force de résistance du point d'attache de la branche chez l'Acer rubrum a été reliée au ratio du diamètre de la branche par rapport à ce lui de la tige-mère où la branche est rattachée (ratio d'aspect). Les coefficients de corrélation linéaire variaient de $-0,25$ à $-0,90$ entre le ratio d'aspect et la force requise pour séparer les branches des tiges-mère au niveau du point d'attache. Les pentes de ces lignes décrivant cette relation augmentaient avec l'accroissement du diamètre de la branche. Ceci indique que les branches plus grosses requièrent une force plus grande pour les arracher du tronc en raison du fait qu'elles sont plus petites comparativement au tronc. Néanmoins, le diamètre a moins d'influence sur la force requise pour séparer d'entre elles deux branches codominantes. La force par surface unitaire de la coupe transversale de la branche a été reliée $\left(\mathrm{r}^{2}\right.$ $=56 \%$ ) au ratio d'aspect, ce qui indiquait qu'une branche d'un diamètre donné était mieux attachée à l'arbre si elle rattachée à une tige-mère plus grosse qu'une tige-mère d'un diamètre équivalent. L'angle d'attache n'a pas été relié à la force d'attache de la branche. Les branche codominantes étaient plus faciles à séparer entre elles que les branches qui étaient petites par rapport à la tige-mère. Les tiges codominantes se brisaient en se séparant à l'endroit de leur point d'attache; les branches tombaient en se brisant au niveau de ou près du collet. Cette information a des implications pour les arboriculteurs qui grimpent dans les arbres et va les aider pour guider le développement de stratégies d'élagage.

Zusammenfassung. Bei Acer rubrum wurde die Stärke der Astanbindung in Beziehung gesetzt mit Durchmesser des Astes in Verhältnis zu der Stärke des Stammes, an welchem er wächst. Die linearen Korrelationskoeffizienten lagen zwischen $-0,25$ bis $-0,90$ zwischen dem Verhältnis und Lasteintrag, welcher erforderlich war, um den Ast von Stamm zu trennen. Die Kurven dieser Linien, die dieses Verhältnis beschrieben, wuchsen mit zunehmendem Astdurchmesser. Das zeigt, dass größere Äste eine größere Kraft erfordern unter der Voraussetzung, dass sie kleiner waren im vergleich zum Stamm. Trotzdem hatte der Durchmesser weniger Einfluss auf die erforderliche Kraft, die aufgewendet werden musste, um kodominante Stämme auseinander zu ziehen. Die Kraft pro Flächeneinheit des Astdurchmessers $\left(\mathrm{r}^{2}=56 \%\right.$ ) wurde in Beziehung gesetzt zum Verhältnis und zeigte, dass Äste einer bestimmten Größe besser an dickeren Stämmen hielten als an Stämmen mit der gleichen Größe. Der Winkel der Anbindung war nicht korreliert mit der Kraft der Anbindung. Kodominante Stämme rissen viel leichter ab als Äste, die relativ klein waren im Vergleich zum Stamm. Kodominante Stämme brachen an der Anbindung während Äste am Astkragen oder in der Nähe abrissen. Diese Informationen haben einige Implikationen für kletternde Baumpfleger und können dazu beitragen, Schnittstrategien zu entwickeln.

Resumen. La fuerza de la unión de la rama en Acer rubrum L. fue asociada a la relación del diámetro de la rama con el diámetro del tronco al cual esta unida (factor relación). Los coeficientes de correlación lineal estuvieron entre -0.25 a -0.90 entre el factor relación y la carga (fuerza) requerida para separar las ramas del tronco de unión. Las pendientes de las líneas que describen esta relación se incrementan con el diámetro de la rama. Esto indicó que las ramas grandes requirieron mayor fuerza para halarlas del tronco puesto que eran pequeñas en comparación con el tronco. Sin embargo, el diámetro tuvo menor influencia en la fuerza requerida para separar los tallos codominantes. La fuerza por unidad de sección de rama estuvo relacionada $\left(\mathrm{r}^{2}=56 \%\right)$ al factor relación indicando que una rama de tamaño dado estaba mejor asegurada al árbol si estaba unida a un tronco mucho más grande que a un tronco de igual tamaño. El ángulo de unión no estuvo relacionado con la fuerza de unión de la rama. Los tallos codominantes fueron más fáciles de separar que las ramas que eran más pequeñas con relación al tamaño del tronco. En los tallos codominantes rotos por la separación en la unión, las ramas fallaron por rotura en o cerca del cuello. Esta información tiene implicaciones para los arbolistas trepadores de árboles y permitirá guiar el desarrollo de las estrategias de poda. 